\title{
THE EFFECTS OF TRANSCULTURAL INFLUENCES IN COMMUNITY PSYCHIATRY AS THEY AFFECT THE COMMUNITY NURSE
}

\author{
E.D.D. Freed M.B. B.ch. (Witwatersrand) \\ D.P.M. F.F. Psyh. (S.A.) M.R.C. Psyh. M.R.A.N.Z.C.P. \\ Staff Psychiatrist, St. Vincent's Hospital, Sydney, Australia \\ formerly part-time psychiatrist and lecturer, \\ Department of Health, Transvaal Provincial Hospitals, \\ and the University of the Witwatersrand
}

Paper presented in September 1979 at the Congress on Community Psychiatry, held by the Psychiatric Discussion Group in Pretoria.

\section{OPSOMMING}

Transkulturele invloede sal die verpleegkundige se siening van gebeure verander. Om so onbevooroordeeld moontlik in haar waarneming en oordeel te wees, moet sy die standpunt van daardie kultuur van binne en buite die kultuur ken. Die verpleegkundige as promotor en die pasiënt as 'n ontvanger word as gelykwaardig in 'n sendontvangsproses gesien. Haar rol as lid van die gesondheidspan in die gemeenskap is dié van sowel leerling as onderwyser.

Daar word beklemtoon dat dit noodsaaklik is om gedurig vrae te stel, die bevindings te bekragtig en by 'n navorsingsprogram vir voortgesette onderwys betrokke te wees.

\section{INTRODUCTION}

Cultural psychiatry concerns itself with the cultural aspects of aetiology, frequency and nature of mental illness and the care and after-care of the mentally ill within the confines of a given cultural unit.

Transcultural psychiatry, which is an extension of cultural psychiatry, denotes that the vista of the scientific observer extends beyond the scope of one cultural unit on to another. (Ruesch. J. 19616)

The attitudes and behaviour of the promoter of health care will affect the attitudes and behaviour of the recipient of this care. In short, to paraphrase $\mathrm{R}$. D. Laing $\left(1967^{5}\right)$. I see you the way you see me seeing you see me ......

In the relationship between nurse or other health care member and patient, there is going to be a resistance to the treatment process if the patient feels that he is being regarded as the inferior member of the two-way dyadic process. The relationship has to be on an equal basis. The health care member may be more knowledgeable and educated.

He has to accept this with humility and regard it as not only a privilege, but his duty, to use his knowledge for the betterment of his fellow man. He has to respect the uniqueness of his fellow man and promote his digni- ty and integrity. This is more difficult in areas where a political polarization may lead to a rigidity on both sides with resultant mutual suspicion and distrust (Freed, E. $\left.1979^{3}\right)$.

The two-way process can be formulated as the I-THOU (Baber M. 1958'). I is equal to THOU and reciprocally THOU is equal to I. (Freed, L.F. 1974 ${ }^{4}$ ).

The perception of reciprocality leads to concord. The absence of this reciprocality is experienced as a cognitive dissonance (which may be formulated as "I am prepared to like you because I should, but I can't because I see you do not like me - as I think you should"'). Dissonance leads to discord. Discord in turn will lead to non-compliance with a health care program and non-co-operation in other areas.

For the purpose of this paper, in order to stress the importance of this reciprocality the term 'promoter' will be used to indicate a member of the health care team and the term 'recipient' will be used to refer to the person who has presented in the role of patient. From time to time the sometimes dispirited health care member hears a "Thank you for helping" and in the context of that message he has become the recipient and the patient has become the promoter. 
For health care to be optimal the interreaction between promotor and recipient has to be optimal. In the first instance, the recipient must perceive an atmosphere (largely subjective) and an attitude (both subjective and objective) of love and caring. Secondly, there has to be an educational process. The promoter has to learn from the recipient what ails him. It might be primarily disease with varying degrees of discomfort or it might be discomfort only, i.e. dis-ease. The symptoms of either will be expressed differently by people of differing personalities and cultural backgrounds.

The meaning of the illness or illness behaviour will vary from family to family (e.g. in a Black family, the father of a hebephrenic schizophrenic boy thought that his son was better because he could do his share of the housework. Under these circumstances, the father did not object to the persistent fatuous smiling. One might disagree with the father in medical model illness terms, but in the father's family relationships terms we have to accept his view).

The promoter has to understand the nature of the recipient's information, e.g. a Black man may say that he hears his ancestors calling him to go home. Depending on other factors, this may or may not be part of a medical model disease process. Nevertheless, implicit in the contents of the statement "My ancestors are calling me to go home" is that the person has felt firstly a feeling of distance from his family (either in fact or symbolically) and secondly he feels the need to move closer to his family (either in fact or symbolically). It is incumbent on the promoter to perceive this and to accept the very real need of the recipient to talk about his family (whether or not there is a disease process present and whether or not the promoter believes in ancestors). The recipient must be made to feel that the promoter understands this need.

The recipient informs the promoter of his family relationships and the promoter discusses with the recipient and his family, ways to resolve or ameliorate the problem. This whole process is an educational one which is what health care is all about. In fact, the outstanding species characteristic of man is educability (Dobzhansky, T., and Montagu A., 1947²).

Health care, whether for the positive promotion of health or for the treatment and prevention of illness is an educational process. This process is a two-way process. The promoter, e.g. the nurse or other member of the health care team and the recipient, sometimes called patient - teach each other and learn from each other. (This is well seen in what one can tell the parents of retarded children, and what one can learn from them as to how they react).

It is incumbent on the promoter, in the process of facilitating his sphere of influence (nursing, doctoring, occupational therapy, social work) to make a diagnosis. In this diagnostic formulation the following must be assessed:-

1. The presence or absence of medical model disease.

2 . The presence or absence of discomfort or dis-ease.

Disease may be asymptomatic, e.g. some cases of hypertension, some cases of schizophrenia. Discomfort, however, may be present without any demonstrable illness, e.g. a discontent with life.

3 . The nature of the underlying personality. In medical terms this is the person behind the lesion. In human transaction terms it is the personality in the liaison between the promoter and the recipient. If they cannot liaise with each other, then the recipient is not likely to enter into a transaction such as a treatment plan.

4 . The family of the recipient (patient) must be seen and understood.

5 . The cultural background of the recipient and his family must be urderstood.

Where the promoter feels that either there is no problem or that the problem is beyond his sphere of influence or competence, he should indicate this but also add that he understands (emphasises) the situation and that apart from other agencies being able to give more specific help, he remains available.

The vital question is: How does someone from one culture get to understand someone from another culture? There are several complementary approaches and processes involved in arriving at such an understanding.

1. Consider an observer A, e.g. nurse - member of a health care team viewing a person $B$ from a different culture. On the first occasion it is like A standing on a straight road and trying to gauge how far away a point $B$ on the horizon is. It is impossible.

However, once A has walked the path on may occasions, he gets a workable assessment in his own mind of the measurements of A B or B in relationship to himself. Using this method only, from the viewpoint at the start of the road (A's culture) his view is bound to be biased. It will contain truths, untruths and distortions.

Therefore, A has to look at the situation from the other way round. ' $A$ ' has to go to the horizon (B's culture) and look back at his position from ' $\mathrm{B}$ 's vantage point. This means many hours of dialogue. It also means becoming familiar with the language, idioms, customs and symbols of B. As a theoretical exercise ' $\mathrm{A}$ ' has to put himself into ' $B$ 's shoes.

In the process of observing, ' $A$ ' has to divest himself of his own cultural beliefs, attitudes and value judgments. In so far as it is possible, 'A' has to take the attitude in the observing-learning process, that he will learn by seeing, listening and asking. He will record the facts and store them in his memory. The facts must be recorded without judgment (e.g. the observation of a man destroying his neighbour's Hi-Fi set - means only that. One cannot infer from that observation itself that there is any madness.

After frequent observations of behaviour and constellations of behaviour, the behaviour can begin to be provisionally interpreted. These interpretations must be validated by consultations with the person's family. Furthermore because of each family's own intrafamilial bias, further validation must be obtained by referring to the wider culture. If necessary, one's 
original interpretations must be modified or even rejected.

2. In the above, we have discussed $A$ viewing ' $B$ ' from ' $A$ 's vantage and then ' $A$ ' pulling himself into ' $B$ 's shoes and trying to view both 'A', from ' $B$ 's vantage point, and ' $B$ ' from 'B's vantage point.

While this bi-directional viewing process is vastly better than the uni-directional, it is not sufficient. When ' $A$ ' looks from either ' $A$ 's vantage point or from ' $B$ 's vantage point, the whole perspective is clouded by 'A's views of himself and his own culture. Again, those views contain truths, relative truths and gross distortions or untruths.

3. To get a further consensual validation about himself and about how he sees others, 'A' should theoretically move to another culture ' $C$ '. He should observe it (as a participant if possible), be observed by it and re-appraise his views of self in the light of the feedback he gets.

This process of continually learning about other people and therefore about oneself must never end. Man has to continually study his whole environment this means not only transculturally of other cultures, but cross-culturally, i.e. comparatively.

4 . Lastly, man has to contemplate on the meaning of life. To do all this he has to get away from all cultures. He has to get away from life as it usually is and meditate. This means a reflection about one's relationship with one's Maker. One has to be alone and undisturbed to do this. Perhaps this is best done in the bushveld or on a mountain top. In the vastness of nature, we can relearn the smaliness of man and ask God as David said: "What is man that Thou art mindful of him?' '

This last learning process is the relearning of faith. Armed with this, the member of the health care team can re-enter the continuous and simultaneous process of being a learner and a teacher, a promotor and a recipient, in his field of work in the family of Man. In conclusion, in looking ahead to the 1980's it is very likely that the teaching emphasis in psychiatry for psychiatrists will be heavily weighed in favour of the biological advances. The reasons for this are beyond the scope of this paper. Psychiatrists may be either less able or less willing to go into the field of community psychiatry.

The nurse has previously been the main bastion in the field of community health in general, and she will remain so. The training, development and experience of the nurse are unique. It behoves the nurse to regard herself as being in a specialized profession and able to make a unique contribution.

Apart from her work in transcultural community psychiatry, she will continue to work both on her own and as an equal member of the multi-disciplinary health care teams. To maintain her position she is going to have to participate in post-graduate courses, in continuing education programs and in research. This research must be done at least partly in the field of transcultural psychiatry. The very explosion of technological advances, that in the medical field will force doctors to be involved in it, will also produce future shocks (Tofler, A.) ${ }^{7}$ and culture shock. Therefore, there will be an increasing need for people with communication skills in the cultural areas of psychiatry.

The nurse will have to be both a pupil learning from her cultural surround, and an educator.

The educational process will involve not only the teaching of those who present in the role of patient, but also the promotion of self-help groups, so that people can help themselves.

\section{RE.FEREYCES}

. Baber, M. (1958): I and Thou. Edinburgh: T and T Clark.

Dobzhansky, T., Montagu, A. (1947): Science 105:587.

Freed, E.D. (1979): "Some psychological phenomena arising in difterent popularion groups out of socio-cultural and socio-political lactors in South Africa: Its implication for doclor-patient underslanding and medical ethics" Leclure given 10 Continuing Education

Freed L.F. (1974): Dochoral Thesis. Mlarin Baber. The Humanist Emphasis in His Philosophy, University of Natal.

Laing, R.D. (1967): The Politics of Experience and the Birds of Puradise. Harmond sworth, Middlesex, England Penguin Books LId.

. Ruesch, J. (1961): Im. J. Soc. Psychiatry, 7.887.

Totler A. Future Shock.

\section{A BABY WITH GASTROSCHISIS}

Gastroschisis is a congenital defect of the abdominal wall, often with protrusion of the viscera. Due to fluid and heat loss from the exposed bowel the baby quickly becomes dehydrated, cold and shocked. Immediate transfer to a suitable centre for surgery and nursing care (a warm incubator, adequate fluid replacement, wound care, antibiotics) is therefore mandatory. Ramdharry (Nursing Times, 6 September $1979: 1547$ ) describes the nursing care of a baby with gastroschisis. The correction of the abdominal defect is of particular interest. Initially the protruding gut was covered with warm salinesaturated gauze until theatre preparations were complete and surgery could be performed. The abdominal defect was enlarged and the protruding viscera were reduced and returned to the abdomen. The uelect was closed by a patch of cadaveric, pre-packed and gamma- irradiated dura and was sutured with silk. The use of dura is new, as Silastic had previously been used, which caused excoriation of the wound. However, using dura, which is natural rather than synthetic, there is less likelihood of breakdown of the wound. Using dura also means that there is no need for its removal. In the case study described, the wound was not dressed at all and the dural patch shrank with the newly formed skin underneath. The sutures were removed from the edge of the dural patch on the twelfth and fourteenth postoperative days and on the nineteentl day the dural patch dropped off, exposing new skin underneath. Initially there was a slight dampness but this dried in less than twenty-four hours. 